Munster, B.C. van, Yazdanpanah, M., Tanck, M.W.T., Rooij, S.E.J.A. de, Giessen, E. van de, Sijbrands, E.J.G., Zwinderman, A.H., Korevaar, J.C. Genetic polymorphisms in the DRD2, DRD3, and SLC6A3 gene in elderly patients with delirium. American Journal of Medical Geneticsi-Part 7

B: Neuropsychiatric Genetics: 2010, 153B(1), 38-45 nivel

\begin{tabular}{|l|l|}
\hline $\begin{array}{l}\text { Postprint } \\
\text { Version }\end{array}$ & 1.0 \\
\hline Journal website & http://onlinelibrary.wiley.com/doi/10.1002/ajmg.b.30943/abstract \\
\hline Pubmed link & http://www.ncbi.nlm.nih.gov/pubmed/19309018 \\
\hline DOI & $10.1002 /$ ajmg.b.30943 \\
\hline
\end{tabular}

This is a NIVEL certified Post Print, more info at http://www.nivel.eu

\title{
Genetic polymorphisms in the DRD2, DRD3, and SLC6A3 gene in elderly patients with delirium $\dagger$
}

\author{
BARbara C. van Munster ${ }^{1,2, *}$, MOJGan YAZDANPANAH ${ }^{3}$, MiCHAEL W.T. TANCK ${ }^{1}$, \\ SOPHIA E.J.A. DE ROOIJ ${ }^{2}$, ELSMARIEKE VAN DE GIESSEN ${ }^{4}$, ERIC J.G. SIJBRANDS ${ }^{3}$, AEILKO H. \\ ZWINDERMAN $^{1}$, JOHANNA C. KOREVAAR ${ }^{1}$ \\ ${ }^{1}$ Department of Clinical Epidemiology, Biostatistics and Bioinformatics, Academic Medical \\ Center, University of Amsterdam, Amsterdam, The Netherlands \\ 2 Department of Internal Medicine, Academic Medical Center, University of Amsterdam, \\ Amsterdam, The Netherlands \\ ${ }^{3}$ Department of Internal Medicine, Erasmus Medical Center, Rotterdam, The Netherlands \\ ${ }^{4}$ Department of Neurogenetics, Academic Medical Center, University of Amsterdam, \\ Amsterdam, The Netherlands
}

\begin{abstract}
Dopamine excess appears to be critical in the final common pathway of delirium. The aim of this study was to investigate whether genetic polymorphisms in three dopamine-related genes (the dopamine receptor 2 (DRD2), dopamine receptor 3 (DRD3), and the dopamine transporter (SLC6A3) gene) were associated with delirium. Patients aged 65 years and older acutely admitted to the medical department or to the surgical department following hip fracture were included. Delirium was diagnosed by the Confusion Assessment Method. Sixteen single nucleotide polymorphisms (SNPs) and one variable number of tandem repeats in the SLC6A3 gene, nine SNPs in the DRD2 gene, and six SNPs in the DRD3 gene were genotyped. Fifty percent of the 115 surgical patients and $34 \%$ of the 605 medical patients experienced delirium. Delirious patients were older and had more frequently pre-existing functional and cognitive impairment $(\mathrm{P}<0.001)$. After correction for multiple testing, one SNP in the SLC6A3 gene (rs393795) was associated with reduced risk of delirium $(\mathrm{P}=0.032)$. Adjusted for age, cognitive impairment, and functional impairment, three SNPs in the DRD2 gene and seven SNPs in the SLC6A3 gene were associated with delirium; none of these associations was significant after correction for multiple testing. Variations in the SLC6A3 gene and possibly the DRD2 gene were associated with delirium. Although validation of these results is needed our results support a role for the dopamine transporter and dopamine receptor 2 in the pathogenesis of delirium. (C) 2009 Wiley-Liss, Inc.
\end{abstract}


Munster, B.C. van, Yazdanpanah, M., Tanck, M.W.T., Rooij, S.E.J.A. de, Giessen, E. van de, Sijbrands, E.J.G., Zwinderman, A.H., Korevaar, J.C. Genetic polymorphisms in the DRD2, DRD3, ) and SLC6A3 gene in elderly patients with delirium. American Journal of Medical Geneticsi-Part 7 B: Neuropsychiatric Genetics: 2010, 153B(1), 38-45

\section{INTRODUCTION}

Delirium is an acute neuropsychiatric syndrome characterized by fluctuating changes in consciousness and attention. A somatic factor, like any medical disease, surgery, substance intoxication, or substance withdrawal, can induce delirium [Frances, 2000]. The syndrome manifests itself in up to $50 \%$ of elderly hospital inpatients, many with pre-existing dementia [Cole, 2004]. Though patients usually recover after treating the precipitating factor, having delirium is independently associated with increased mortality, impaired physical and cognitive recovery, and increased healthcare costs [Inouye, 2006].

There are a few candidate gene association studies on delirium in the elderly, yet they are performed in small populations and mostly limited to the association with the apolipoprotein $\varepsilon 4$ allele, with conflicting results [Adamis et al., 2007; Leung et al., 2007; Tagarakis et al., 2007; van Munster et al., 2007b; Gunther et al., 2008]. Genetics of delirium due to alcohol withdrawal has been studied more often, mainly in small studies as well [van Munster et al., 2007a]. In two independent study populations, polymorphisms in the dopamine receptor 3 gene (DRD3) on the 3q13.3 chromosome and the dopamine transporter (SLC6A3) gene on the $5 \mathrm{p} 15.3$ chromosome were found to be associated with alcohol withdrawal delirium [van Munster et al., 2007a].

Although the pathophysiological mechanisms of alcohol withdrawal delirium and delirium in the elderly may differ, dopamine appears to have a role in both syndromes [Trzepacz, 2000; van Munster et al., 2007a]. Dopamine is involved in all characteristics that are often disturbed during delirium like attention, locomotion, memory, and perception. Dopaminergic substances can contribute to delirium, and dopamine receptor 2 antagonists are helpful in providing symptomatic relief of delirium [Alagiakrishnan and Wiens, 2004]. The dopamine receptor 2 (DRD2) gene on the 11q22-q24 chromosome is one of the most frequently studied genes in complex behavioral disorders and is associated with diverse delirium-overlapping phenotypes, like attention deficit hyperactivity disorder, schizophrenia, and movement disorders. The SLC6A3 gene is coding for the dopamine transporter, which regulates extracellular dopamine concentrations [van Dyck et al., 2005]. A subpopulation of DRD3 receptors modulate neuronal activity of dopamine [Levant, 1997].

These findings suggest that the DRD2, the DRD3, and the SLC6A3 genes are eligible candidate genes for association studies with delirium. The aim of this study was to investigate whether genetic polymorphisms in the DRD2, the DRD3, and the SLC6A3 genes were associated with delirium in a population of acutely admitted older patients.

\section{MATERIALS AND METHODS}

\section{Patients}

From April 2003 through August 2007, consecutive medical patients 65 years of age or older who were acutely admitted to the Academic Medical Centre, Amsterdam, were invited to participate. From June 2005 till August 2007 also hip fractures patients of 65 years and above admitted to the Department of Orthopedic Surgery or Traumatology and scheduled for surgery were included. Informed consent was obtained from all patients or closest proxy in cases of cognitive impairment. Patients were excluded if they were unable to speak or understand Dutch or English. The institutional Medical Ethics Committee approved the study. The final sample size was limited by the time period for inclusion, which is time consuming since the syndrome has to be diagnosed shortly after admission for an acute illness.

\section{Procedures}

Two geriatric physicians, a fellow in geriatric medicine, and four research nurses trained in geriatric medicine collected demographic and clinical data. The presence or absence of delirium was scored within $48 \mathrm{hr}$ of admission using the Confusion Assessment Method (CAM) [Inouye et al., 1990]. We based our information for the diagnosis on our psychiatric 
Munster, B.C. van, Yazdanpanah, M., Tanck, M.W.T., Rooij, S.E.J.A. de, Giessen, E. van de, Sijbrands, E.J.G., Zwinderman, A.H., Korevaar, J.C. Genetic polymorphisms in the DRD2, DRD3, ) and SLC6A3 gene in elderly patients with delirium. American Journal of Medical Geneticsi-Part 7 B: Neuropsychiatric Genetics: 2010, 153B(1), 38-45

examination of the patient, medical, and nursing records including the Delirium Observation Screening Scale (DOS) [Schuurmans et al., 2003], and information given by the patient's proxy. Possible confounding factors, including demography, use of alcohol, cognitive and physical functioning, were registered for all patients.

Pre-existing cognitive functioning was scored at the time of hospital admission by two validated instruments, the Informant Questionnaire on COgnitive DEcline (IQCODE) [Jorm, 1994] and the Mini-Mental State Examination (MMSE) [Folstein et al., 1975]. For the IQCODE, the informant was asked to recollect the situation 2 weeks before the illness started for which the patient had been admitted and to compare it with the situation 10 years before. Patients with a mean score of 3.9 or more were considered to have global cognitive impairment [de Jonghe, 1997]. We applied the MMSE as suggested by Heeren et al. 1990 and took a cut-off score of less than 24 indicating cognitive impairment. Pre-existing cognition was scored to be impaired when participants had a medical history of dementia of any cause or had an IQCODE above the cut-off score. In case of missing IQCODE we used the MMSE for patients without delirium. To measure physical functionality, we asked patients or their closest relative in cases of cognitive impairment to complete the 15-item Katz Index of Activities of Daily Living (ADL) based on the situation 2 weeks prior to admission [Weinberger et al., 1992]. Patients with a score of 7 and more were considered as functional impaired.

\section{Single Nucleotide Polymorphisms (SNPs) Selection and Genotyping}

Genomic DNA was isolated from $10 \mathrm{ml}$ of whole blood on an AutopureLS apparatus according to a protocol provided by the manufacturer (Gentra Systems, Minneapolis, MN). Genotyping was performed blinded. Based on HapMap (Phase 2) information on their ability to tag major haplotype variation in the gene, with R2 cut-off 0.8 and minimum allele frequency cut-off $0.2,7$ tagging SNPs were chosen for the DRD2 gene, 14 for the SLC6A3 gene, and 6 for the DRD3 gene. Based on potential functionality from the literature we added two SNPs [rs27072, Ueno et al., 1999 and rs2652511, Rubie et al., 2001] and the variable number of tandem repeats (VNTR) of

"ACTGGAGCGTGTACTACCCCAGGACGCATGCAGGGCCCCC" [Vandenbergh et al., 1992] in the SLC6A3 gene, and two SNPs [rs1800497, Blum et al., 1990 and rs1799732, Arinami et al., 1997] in the DRD2 gene. An important functional SNP in the DRD3 gene [rs6280, van Munster et al., 2007a] was one of the tagging SNPs.

All SNPs were determined using Taqman allelic discrimination Assay-By-Design (Applied Biosystems, Foster City, CA). Primer and probe sequences are presented in the Supplement Table Ia-c. We used the reverse strand design for the rs6347, rs27072, rs10053602, rs4975646, rs1042098, rs2975292, rs11133767, rs393795, rs27048 polymorphisms of the SLC6A3 gene and rs6277, rs17601612, rs17529477, rs1800497, rs2734839 polymorphisms of the DRD2 gene, and rs2134655, rs324035 polymorphisms of the DRD3 gene. The assays utilized 2 ng of genomic DNA and $2 \mu 1$ of reaction volumes. The amplification and extension protocol was as follows: an initial activation step of $10 \mathrm{~min}$ at $95^{\circ}$ preceded 40 cycles of denaturation at $95^{\circ}$ for $15 \mathrm{sec}$ and annealing and extension at $50^{\circ}$ for $60 \mathrm{sec}$. Allele-specific fluorescence was then analyzed on an ABI prism $7900 \mathrm{HT}$ sequence detection system, version 2.2 (Applied Biosystems). The VNTR in the SLC6A3 gene was amplified from the DNA by polymerase chain reaction (PCR), following standard protocol and using the primers described by Vandenbergh et al. 1992. The assays utilized 20 ng of DNA in a $10 \mu 1$ of reaction volume. PCR products for VNTR analysis were separated by gel electrophoresis in $3 \%$ agarose gel stained with ethidium bromide. All results were scored blinded to delirium status.

\section{Statistics}

Statistical Package for the Social Sciences (SPSS), version 15.0 was used for data analysis. We tested for differences in characteristics in patients with and without delirium using t-tests and Mann-Whitney U-tests. A two-tailed P-value of below 0.05 was considered statistically 
Munster, B.C. van, Yazdanpanah, M., Tanck, M.W.T., Rooij, S.E.J.A. de, Giessen, E. van de, Sijbrands, E.J.G., Zwinderman, A.H., Korevaar, J.C. Genetic polymorphisms in the DRD2, DRD3, and SLC6A3 gene in elderly patients with delirium. American Journal of Medical Geneticsi-Part 7 B: Neuropsychiatric Genetics: 2010, 153B(1), 38-45

significant. Chi-square tests were used for Hardy-Weinberg and association analysis with delirium of all SNPs and the 9 or 10 repeat of the VNTR separately. The association between every SNPs and delirium was investigated by multivariable logistic regression analysis adjusted for independent risk factors for delirium. Independent risk factors were determined by backward selection procedure of multivariable logistic regression analyses with significant factors of Table I. Correction for multiple testing was done by calculating false discovery rate (FDR) [Benjamini and Hochberg, 2007], and we considered FDR P-value below 0.05 as statistically significant. Next, multivariable logistic analyses with forward selection procedure were performed with age, cognitive and functional impairment and all SNPs with P-value below 0.05 of the former analyses. Haplotype blocks were identified using the confidence intervals algorithm implemented in Haploview [Gabriel et al., 2002; Barrett et al., 2005]. Haplotype effects and frequencies were jointly estimated using an EM algorithm in which individual haplotypes were handled as missing data [Souverein et al., 2006].

\section{[TABLE 1]}

\section{RESULTS}

\section{Study Population}

Figure 1 shows the flow diagram of the patient selection process. Of a total of 1,133 available patients, blood samples were available for 734 patients, of whom 8 CAM scores were missing and 6 patients were not successfully genotyped for any of the SNPs. This resulted in 115 patients admitted with a hip fracture (50\% with delirium) and 605 acutely admitted patients to the Department of Medicine (34\% with delirium). There were no significant differences in the included surgical patients compared with the non-included with respect to age, length of stay, or frequency of delirium. The included medical patients were slightly older ( 78 vs. $77, \mathrm{P}=0.04$ ) and were significantly longer admitted (median 9 vs. 6 days, $\mathrm{P}<0.001$ ) compared to the non-included patients. Characteristics of these 720 patients with and without delirium are presented in Table I. Delirious patients were significantly older $(\mathrm{P}<0.001)$ and had more frequently pre-existing functional $(\mathrm{P}<0.001)$ and cognitive impairment $(\mathrm{P}<.001)$ than patients without delirium.

\section{[FIGURE 1]}

\section{Genotyping}

Determination of SNPs had success rates between 92\% and 97\%. All SNPs in the three candidate genes were in Hardy-Weinberg equilibrium (HWE) in the total study population. Tables IIa-IIc show the analysis of delirium with all SNPs and the 9 and 10 repeat of the VNTR. After correction for multiple testing a variation in the SLC6A3 gene (rs393795) was shown to be protective for the development of delirium ( $\mathrm{P}=0.032)$, while none of the variations in the DRD3 gene and the DRD2 gene were significantly associated with delirium.

\section{[TABLE 2A]}

\section{[TABLE 2B]}

\section{[TABLE 2C]}

Delirium was independently associated with older age (odds ratio $(\mathrm{OR})=1.08,95 \% \mathrm{CI}$ : 1.06-1.11, $\mathrm{P}<.001)$, cognitive impairment ( $\mathrm{OR}=15.8,95 \% \mathrm{CI}: 10.5-23.7, \mathrm{P}<0.001)$ and functional impairment $(\mathrm{OR}=5.2 \mathrm{CI}: 3.8-7.3, \mathrm{P}<0.001)$ in logistic regression analyses. After 
Munster, B.C. van, Yazdanpanah, M., Tanck, M.W.T., Rooij, S.E.J.A. de, Giessen, E. van de, Sijbrands, E.J.G., Zwinderman, A.H., Korevaar, J.C. Genetic polymorphisms in the DRD2, DRD3, ) and SLC6A3 gene in elderly patients with delirium. American Journal of Medical Geneticsi-Part 7 B: Neuropsychiatric Genetics: 2010, 153B(1), 38-45

adjusting for these three factors, three SNPs in the DRD2 gene and seven SNPs in the SLC6A3 gene were significantly associated with delirium (Table III). After correction for multiple testing, none of these associations remained significant. No significant associations were found between delirium and the DRD3 gene. Combining the significant SNPs of the DRD2 and SLC6A3 genes in a multivariable logistic regression model with age, cognitive impairment, and functional impairment was possible in 565 patients and resulted in a significant effect of two SNPs of the SLC6A3 gene (rs1042098, P=0.04) and (rs393795, $\mathrm{P}=0.007$ ) and one SNP of the DRD2 gene (rs6276, $\mathrm{P}=0.001$ ) (Table III). Homozygous A allele for SLC6A3 showed a $80 \%$ decrease for the risk of delirium (Table III). Haplotype analysis in 425 patients with complete genotype revealed no statistically significant association (data not shown).

\section{[TABLE 3]}

\section{DISCUSSION}

In this study among elderly patients acutely admitted to a medical department or surgical department with hip fracture, the AA genotype of the SLC6A3 gene (rs393795) was shown to be protective for the development of delirium. Furthermore, we observed that three SNPs in the DRD2 gene and seven SNPs in the SLC6A3 gene, including rs393795, were associated with delirium, after adjustment for age, cognitive impairment, and functional impairment. The haplotype analysis revealed no results of interest, which could be explained by the use of tagging SNPs, which are defined to cover haplotype blocks.

Our study population of acutely admitted elderly patients seemed to be a representative cross-section of the elderly hospital population. The frequency of delirium of $50 \%$ in hip fracture patients and of $34 \%$ in medical patients has been found in other large studies [Siddiqi et al., 2006; Bruce et al., 2007]. Higher age, pre-existing functional and cognitive impairment, and dependent living conditions are all associated with delirium according to this study. These findings are in line with our expectations, since they are all well-known risk factors for delirium in the literature [Elie et al., 1998]. The fact that after correction for these well-known risk factors for delirium SNPs in the DRD2 and SLC6A3 gene were associated with delirium makes the contribution of genetics in the development of delirium plausible. Since delirium is a complex phenotype to define, heritability studies and linkage analyses in families are lacking. Utilization of large-scale association studies followed by multivariable analyses, which include environmental as well as genetic data, will likely be far better than traditional candidate gene approach in disentangling the complex genetics of psychiatric disorders. However, genetic research in delirium is only starting and large cohorts for reliable validation are not yet available.

Given the fact that in all different analyses the SNP (rs393795) in the SLC6A3 gene was associated with delirium, a true association seems probable. Up to now, this polymorphism has never been described in relation to any disease. The genetic constitution of the SLC6A3 gene can affect the availability or function of dopamine transporters in the striatum and because of that influence the dopamine concentration [van Dyck et al., 2005; Nikolaus et al., 2007]. A lower cerebral basal dopamine concentration in patients with the mutant genotype of the SLC6A3 gene could diminish the risk for delirium. The other SNP of interest in the SLC6A3 gene rs40184 is associated with bipolar disorder and conduct disorder in children, which shows some overlapping symptoms with delirium [Mick et al., 2008].

The three polymorphisms in the DRD2 gene (rs6276, rs6277, and rs2734839) were all independently associated with delirium after adjustment for the most important risk factors for delirium. All are non-coding polymorphisms, although two of them do have a possible effect on the dopamine regulation. The rs6276 SNP has been described in association with various alcohol-related phenotypes, which might be due to a lower transcription/translation rate resulting in decreased D2 protein availability [Lucht et al., 2007]. The rs6277 SNP, 
Munster, B.C. van, Yazdanpanah, M., Tanck, M.W.T., Rooij, S.E.J.A. de, Giessen, E. van de, Sijbrands, E.J.G., Zwinderman, A.H., Korevaar, J.C. Genetic polymorphisms in the DRD2, DRD3, and SLC6A3 gene in elderly patients with delirium. American Journal of Medical Geneticse-Part 7 B: Neuropsychiatric Genetics: 2010, 153B(1), 38-45

which alters mRNA stability and dopamine-induced up regulation of DRD2 expression in cell cultures and DRD2 mRNA translation in vitro, is described in association with schizophrenia [Monakhov et al., 2008]. Interestingly, interaction between the dopamine transporter and the DRD2 gene could possibly play a role since a different polymorphism in the DRD2 gene (rs1800497) is associated with higher density of the dopamine transporter [Laine et al., 2001].

Based on polymorphisms associated with alcohol-withdrawal delirium, we would have expected to find also an association between delirium and SNPs in the DRD3 gene [van Munster et al., 2007a]. A possible explanation for the lack of association in the present study is that alcohol-withdrawal delirium is a syndrome with overlapping symptoms but with a different pathophysiology.

In conclusion, this study adds to the evidence of the role of genetics in the development of delirium. Although validation of these results is needed, the positive associations of polymorphisms in both the SLC6A3 and DRD2 gene with delirium make a role for the dopamine transporter and dopamine receptor 2 in the pathogenesis of delirium plausible.

\section{ACKNOWLEDGEMENTS}

The authors wish to thank the research nurses, A.W.J. Giesbers, J.L. Popma, C.M.M. van Rijn, A.C.L. Scheffer, and M.J.A. van der Zwaan and the technicians of the genetic laboratory, E.J. Bradley and L.C. van der Zee.

Data collection performed by Dr. B.C. van Munster, Dr. S.E.J.A. de Rooij and research nurses A.W.J. Giesbers, J.L. Popma, C.M.M. van Rijn, A.C.L. Scheffer, and M.J.A. van der Zwaan. Genotyping performed by a research technician L.C. van der Zee of the Lipid Clinic, Department of Internal Medicine under the supervision of Dr. M. Yazdanpanah and Dr. E.J.G. Sijbrands. E.M. van de Giessen performed the VNTR genotyping. Data analysis performed by Dr. B.C. van Munster under supervision of Dr. M.W. Tanck, Dr. J.C. Korevaar, and Prof. A.H. Zwinderman. All of the above contributed to the writing of the manuscript.

\section{REFERENCES}

Adamis D, Treloar A, Martin FC, Gregson N, Hamilton G, Macdonald AJ. 2007. APOE and cytokines as biological markers for recovery of prevalent delirium in elderly medical inpatients. Int J Geriatr Psychiatry 22: 688-694.

Alagiakrishnan K, Wiens CA. 2004. An approach to drug induced delirium in the elderly. Postgrad Med J 80: 388-393.

Arinami T, Gao M, Hamaguchi H, Toru M. 1997. A functional polymorphism in the promoter region of the dopamine D2 receptor gene is associated with schizophrenia. Hum Mol Genet 6: 577-582.

Barrett JC, Fry B, Maller J, Daly MJ. 2005. Haploview: Analysis and visualization of LD and haplotype maps. Bioinformatics 21: 263-265.

Benjamini Y, Hochberg Y. 2007. Controlling the false discovery rate: A practical and powerful approach to multiple testing. J R Stat Soc Ser B 57: 289-300.

Blum K, Noble EP, Sheridan PJ, Montgomery A, Ritchie T, Jagadeeswaran P, et al. 1990. Allelic association of human dopamine D2 receptor gene in alcoholism. J Am Med Assoc 263: 2055-2060.

Bruce AJ, Ritchie CW, Blizard R, Lai R, Raven P. 2007. The incidence of delirium associated with orthopedic surgery: A meta-analytic review. Int Psychogeriatr 19: 197-214.

Cole MG. 2004. Delirium in elderly patients. Am J Geriatr Psychiatry 12: 7-21.

de Jonghe JF. 1997. Differentiating between demented and psychiatric patients with the Dutch version of the IQCODE. Int J Geriatr Psychiatry 12: 462-465.

Elie M, Cole MG, Primeau FJ, Bellavance F. 1998. Delirium risk factors in elderly hospitalized patients. J Gen Intern Med 13: 204-212.

Folstein MF, Folstein SE, McHugh PR. 1975. "Mini-mental state". A practical method for grading the cognitive state of patients for the clinician. J Psychiatr Res 12: 189-198. 
Munster, B.C. van, Yazdanpanah, M., Tanck, M.W.T., Rooij, S.E.J.A. de, Giessen, E. van de, Sijbrands, E.J.G., Zwinderman, A.H., Korevaar, J.C. Genetic polymorphisms in the DRD2, DRD3, ) and SLC6A3 gene in elderly patients with delirium. American Journal of Medical Geneticsi-Part 7 B: Neuropsychiatric Genetics: 2010, 153B(1), 38-45

Frances AJ. 2000. Diagnostic, Statistical Manual of Mental Disorders: DSM IV-TR. Washington, DC: American Psychiatric Association.

Gabriel SB, Schaffner SF, Nguyen H, Moore JM, Roy J, Blumenstiel B, et al. 2002. The structure of haplotype blocks in the human genome. Science 296: 2225-2229.

Gunther ML, Morandi A, Ely EW. 2008. Pathophysiology of delirium in the intensive care unit. Crit Care Clin 24: 45-65.

Heeren TJ, Lagaay AM, von Beek WC, Rooymans HG, Hijmans W. 1990. Reference values for the Mini-Mental State Examination (MMSE) in octo- and nonagenarians. J Am Geriatr Soc 38: 1093-1096.

Inouye SK. 2006. Delirium in older persons. N Engl J Med 354: 1157-1165.

Inouye SK, van Dyck CH, Alessi CA, Balkin S, Siegal AP, Horwitz RI. 1990. Clarifying confusion: The confusion assessment method. A new method for detection of delirium. Ann Intern Med 113: 941-948.

Jorm AF. 1994. A short form of the Informant Questionnaire on Cognitive Decline in the Elderly (IQCODE): Development and cross-validation. Psychol Med 24: 145-153.

Laine TP, Ahonen A, Rasanen P, Pohjalainen T, Tiihonen J, Hietala J. 2001. The A1 allele of the $\mathrm{D} 2$ dopamine receptor gene is associated with high dopamine transporter density in detoxified alcoholics. Alcohol Alcohol 36: 262-265.

Leung JM, Sands LP, Wang Y, Poon A, Kwok PY, Kane JP, et al. 2007. Apolipoprotein E e4 allele increases the risk of early postoperative delirium in older patients undergoing noncardiac surgery. Anesthesiology 107: 406-411.

Levant B. 1997. The D3 dopamine receptor: Neurobiology and potential clinical relevance. Pharmacol Rev 49: 231-252.

Lucht M, Barnow S, Schroeder W, Grabe HJ, Rosskopf D, Brummer C, et al. 2007. Alcohol consumption is associated with an interaction between DRD2 exon $8 \mathrm{~A} / \mathrm{A}$ genotype and self-directedness in males. Neuropsychobiology 56: 24-31.

Mick E, Kim JW, Biederman J, Wozniak J, Wilens T, Spencer T, et al. 2008. Family based association study of pediatric bipolar disorder and the dopamine transporter gene (SLC6A3). Am J Med Genet Part B 147B: 1182-1185.

Monakhov M, Golimbet V, Abramova L, Kaleda V, Karpov V. 2008. Association study of three polymorphisms in the dopamine D2 receptor gene and schizophrenia in the Russian population. Schizophr Res 100: 302-307.

Nikolaus S, Antke C, Kley K, Poeppel TD, Hautzel H, Schmidt D, et al. 2007. Investigating the dopaminergic synapse in vivo. I. Molecular imaging studies in humans. Rev Neurosci 18: 439-472.

Rubie C, Schmidt F, Knapp M, Sprandel J, Wiegand C, Meyer J, et al. 2001. The human dopamine transporter gene: The 5 '-flanking region reveals five diallelic polymorphic sites in a Caucasian population sample. Neurosci Lett 297: 125-128.

Schuurmans MJ, Shortridge-Baggett LM, Duursma SA. 2003. The Delirium Observation Screening Scale: A screening instrument for delirium. Res Theory Nurs Pract 17: 31-50.

Siddiqi N, House AO, Holmes JD. 2006. Occurrence and outcome of delirium in medical inpatients: A systematic literature review. Age Ageing 35: 350-364.

Souverein OW, Zwinderman AH, Tanck MW. 2006. Estimating haplotype effects on dichotomous outcome for unphased genotype data using a weighted penalized loglikelihood approach. Hum Hered 61: 104-110.

Tagarakis GI, Tsolaki-Tagaraki F, Tsolaki M, Diegeler A, Tsilimingas NB, Papassotiropoulos A. 2007. The role of apolipoprotein $E$ in cognitive decline and delirium after bypass heart operations. Am J Alzheimers Dis Other Demen 22: 223-228.

Trzepacz PT. 2000. Is there a final common neural pathway in delirium? Focus on acetylcholine and dopamine. Semin Clin Neuropsychiatry 5: 132-148.

Ueno S, Nakamura M, Mikami M, Kondoh K, Ishiguro H, Arinami T, et al. 1999. Identification of a novel polymorphism of the human dopamine transporter (DAT1) gene and the significant association with alcoholism. Mol Psychiatry 4: 552-557.

van Dyck CH, Malison RT, Jacobsen LK, Seibyl JP, Staley JK, Laruelle M, et al. 2005. Increased dopamine transporter availability associated with the 9-repeat allele of the SLC6A3 gene. J Nucl Med 46: 745-751. 
Munster, B.C. van, Yazdanpanah, M., Tanck, M.W.T., Rooij, S.E.J.A. de, Giessen, E. van de, Sijbrands, E.J.G., Zwinderman, A.H., Korevaar, J.C. Genetic polymorphisms in the DRD2, DRD3, and SLC6A3 gene in elderly patients with delirium. American Journal of Medical Geneticsi-Part 7 B: Neuropsychiatric Genetics: 2010, 153B(1), 38-45

van Munster BC, Korevaar JC, de Rooij SE, Levi M, Zwinderman AH. 2007a. Genetic polymorphisms related to delirium tremens: A systematic review. Alcohol Clin Exp Res 31: 177-184.

van Munster BC, Korevaar JC, de Rooij SE, Levi M, Zwinderman AH. 2007b. The association between delirium and the apolipoprotein $\mathrm{E}$ epsilon4 allele in the elderly. Psychiatr Genet 17: 261-266.

Vandenbergh DJ, Persico AM, Hawkins AL, Griffin CA, Li X, Jabs EW, et al. 1992. Human dopamine transporter gene (DAT1) maps to chromosome 5p15.3 and displays a VNTR. Genomics 14: 1104-1106.

Weinberger M, Samsa GP, Schmader K, Greenberg SM, Carr DB, Wildman DS. 1992. Comparing proxy and patients' perceptions of patients' functional status: Results from an outpatient geriatric clinic. J Am Geriatr Soc 40: 585-588.

\section{TABLES AND FIGURES}

Table 1

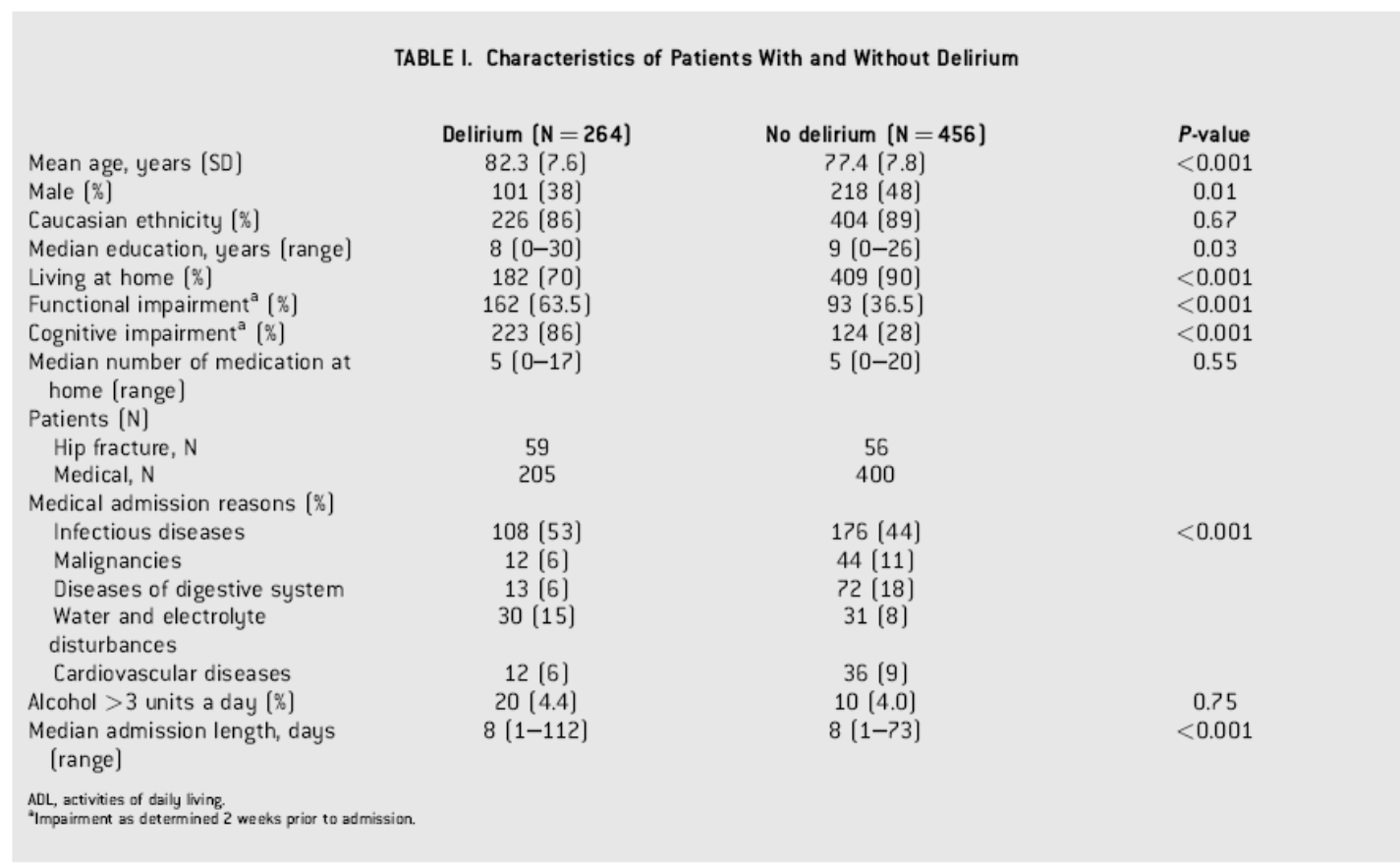


Munster, B.C. van, Yazdanpanah, M., Tanck, M.W.T., Rooij, S.E.J.A. de, Giessen, E. van de, Sijbrands, E.J.G., Zwinderman, A.H., Korevaar, J.C. Genetic polymorphisms in the DRD2, DRD3, and SLC6A3 gene in elderly patients with delirium. American Journal of Medical Geneticsi-Part 7 B: Neuropsychiatric Genetics: 2010, 153B(1), 38-45

\section{Figure 1}

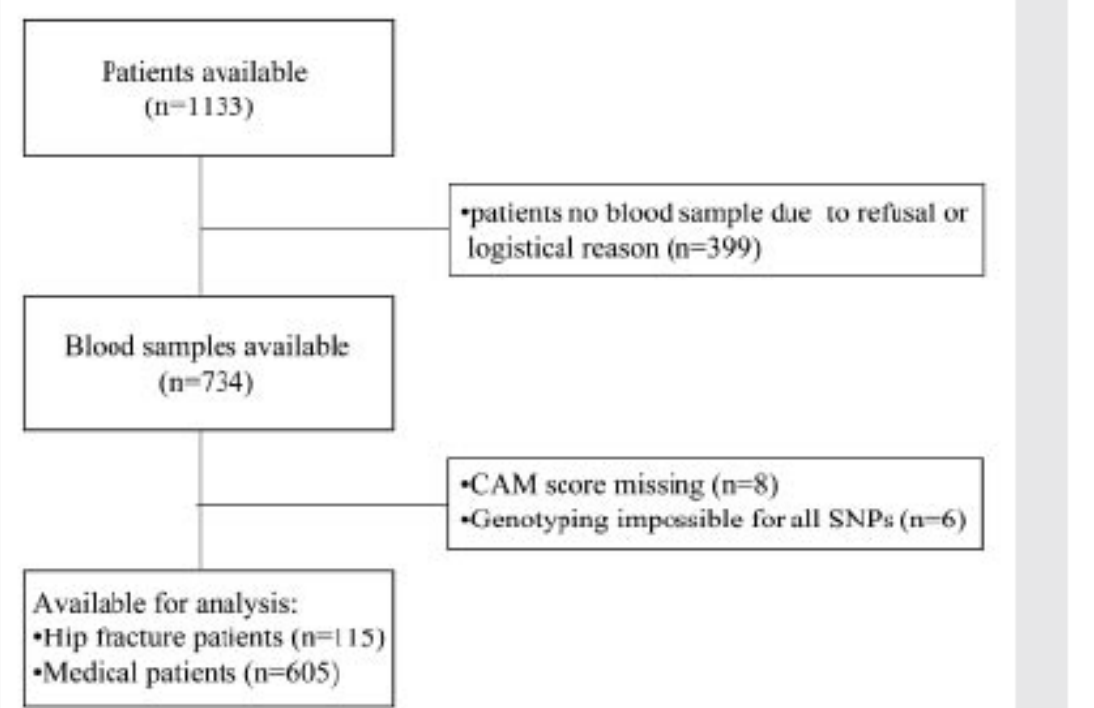

FIG. 1. Flow diagram of patient selection process. 
Munster, B.C. van, Yazdanpanah, M., Tanck, M.W.T., Rooij, S.E.J.A. de, Giessen, E. van de, Sijbrands, E.J.G., Zwinderman, A.H., Korevaar, J.C. Genetic polymorphisms in the DRD2, DRD3, and SLC6A3 gene in elderly patients with delirium. American Journal of Medical Geneticsi-Part 7 B: Neuropsychiatric Genetics: 2010, 153B(1), 38-45

Table 2a

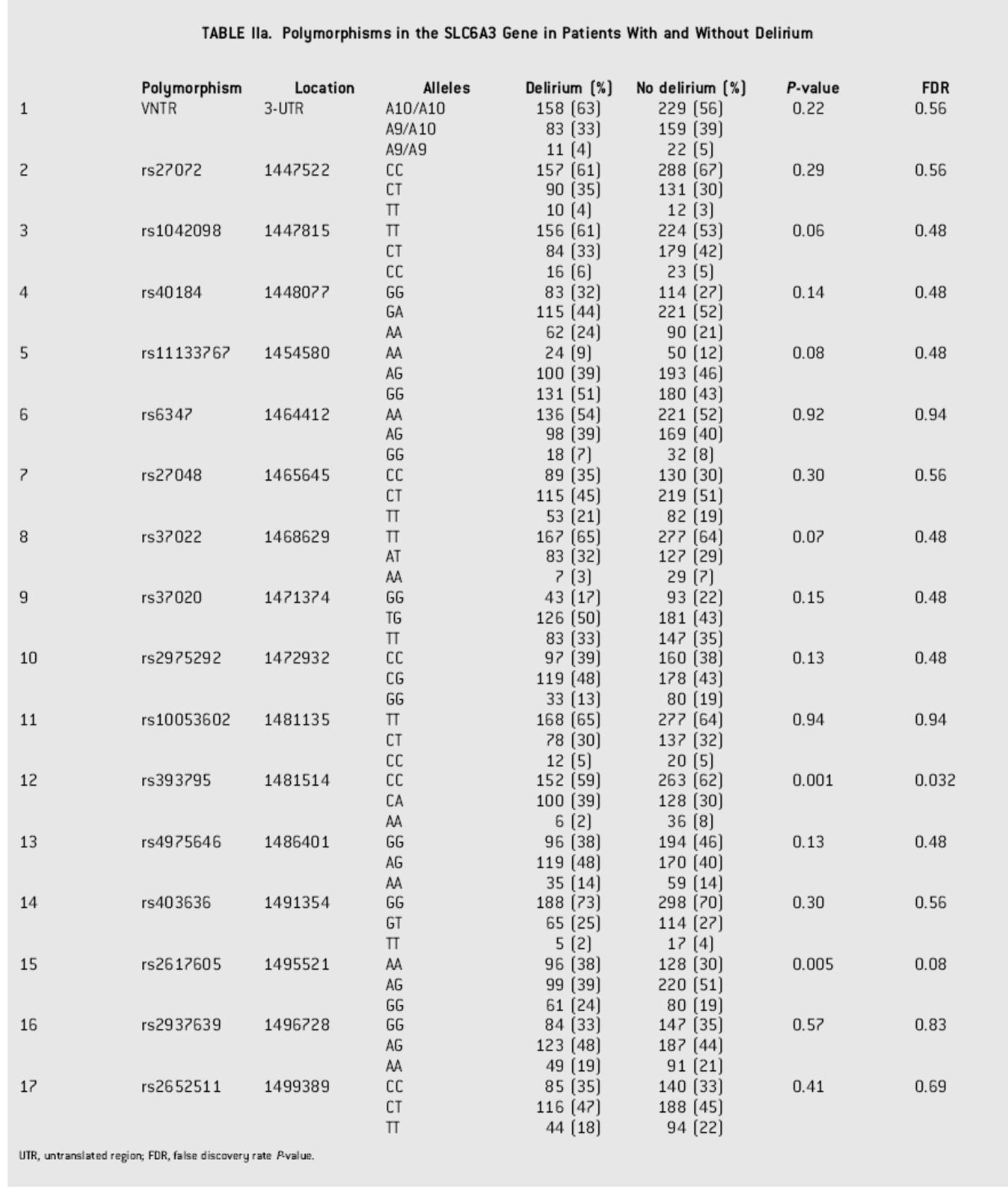


Munster, B.C. van, Yazdanpanah, M., Tanck, M.W.T., Rooij, S.E.J.A. de, Giessen, E. van de, Sijbrands, E.J.G., Zwinderman, A.H., Korevaar, J.C. Genetic polymorphisms in the DRD2, DRD3, and SLC6A3 gene in elderly patients with delirium. American Journal of Medical Geneticsi-Part 7 B: Neuropsychiatric Genetics: 2010, 153B(1), 38-45

\section{Table 2b}

\begin{tabular}{|c|c|c|c|c|c|c|c|c|}
\hline & Polymorphism & Location & & Allele & Delirium [\%] & No delirium [\%] & $P$-value & FDR \\
\hline \multirow[t]{3}{*}{1} & rs180049? & 112776038 & CC & & $160(63)$ & 269 [66] & 0.79 & 0.90 \\
\hline & & & СТ & & 83 [33] & $126(31)$ & & \\
\hline & & & $\Pi$ & & $10[4]$ & 14 (3) & & \\
\hline \multirow[t]{3}{*}{2} & rs6276 & $11278660 ?$ & AA & & 125 (50) & 190 (46] & 0.27 & 0.56 \\
\hline & & & $A G$ & & 99 (40) & 172 [41] & & \\
\hline & & & GG & & 24 (10) & 56 (13) & & \\
\hline \multirow[t]{3}{*}{3} & rs627? & 112788669 & $\Pi$ & & 85 (34) & 121 (29) & 0.22 & 0.56 \\
\hline & & & TC & & 114 (46) & 199 (47) & & \\
\hline & & & CC & & 50 (20) & 104 (25) & & \\
\hline \multirow[t]{3}{*}{4} & rs2734839 & 112791700 & AA & & 100 [39] & 170 (39) & 0.35 & 0.62 \\
\hline & & & $A G$ & & 126 (49) & 194 (45] & & \\
\hline & & & GG & & 32 (12) & 70 (16) & & \\
\hline \multirow[t]{3}{*}{5} & rs1752947? & $11282227 ?$ & GG & & 121 [48] & $188[44]$ & 0.15 & 0.48 \\
\hline & & & $A G$ & & 106 [42] & 172 [41] & & \\
\hline & & & AA & & 24 (10) & 62 (15] & & \\
\hline \multirow[t]{3}{*}{6} & rs17601612 & 112822955 & GG & & 97 (38) & 153 (35) & 0.23 & 0.56 \\
\hline & & & CG & & 126 (49) & 197 (46] & & \\
\hline & & & $\mathrm{CC}$ & & 36 [14] & 82 [19] & & \\
\hline \multirow[t]{3}{*}{$?$} & rs424514? & 112823217 & $\mathrm{CC}$ & & 68 [27] & 117 [27] & 0.87 & 0.94 \\
\hline & & & CT & & 121 (48] & 213 (50) & & \\
\hline & & & $\pi$ & & 63 [25] & 100 (23) & & \\
\hline \multirow[t]{3}{*}{8} & rs?131056 & 112834984 & CC & & 74 (29) & 144 [33] & 0.51 & 0.78 \\
\hline & & & $\mathrm{AC}$ & & 133 [52] & 211 (49) & & \\
\hline & & & AA & & 49 (19) & 79 [18] & & \\
\hline \multirow[t]{3}{*}{9} & rs1799732 & 112851462 & $\mathrm{CC}$ & & $206[81]$ & 346 [81] & 0.63 & 0.88 \\
\hline & & & c. & & 43 (1?] & ?? (18) & & \\
\hline & & & - & & 6 [2] & 6 (1) & & \\
\hline
\end{tabular}

\section{Table 2c}

\begin{tabular}{|c|c|c|c|c|c|c|c|}
\hline \multirow{3}{*}{1} & Polymorphism & Location & Allele & Delirium [\%] & No delirium [\%] & $P$-value & FDR \\
\hline & rs2134655 & 115340891 & GG & 159 [61] & $244(56)$ & 0.43 & 0.69 \\
\hline & & & $\begin{array}{l}\mathrm{GA} \\
\mathrm{AA}\end{array}$ & $\begin{array}{l}89[34] \\
13[5]\end{array}$ & $\begin{array}{c}162[38] \\
28[?]\end{array}$ & & \\
\hline \multirow[t]{3}{*}{2} & rs963468 & $1153455 ? 7$ & GG & 91 [35] & 165 [38] & 0.70 & 0.90 \\
\hline & & & $A G$ & 124 [48] & 204 (4?] & & \\
\hline & & & AA & 44 (17) & 66 [15] & & \\
\hline \multirow[t]{3}{*}{3} & rs324035 & 115351544 & CC & $158[63]$ & 272 [64] & 0.69 & 0.90 \\
\hline & & & $A C$ & 78 [31] & 135 [32] & & \\
\hline & & & AA & $17[?]$ & $22[5]$ & & \\
\hline \multirow[t]{3}{*}{4} & rs11721264 & 115362094 & GG & $124[48]$ & 215 (50) & 0.76 & 0.90 \\
\hline & & & $A G$ & 109 [43] & $173[40]$ & & \\
\hline & & & AA & 23 [9] & 44 (10) & & \\
\hline \multirow[t]{3}{*}{5} & rs6280 & 115373505 & $\pi$ & 106 [41] & $186[43]$ & 0.89 & 0.94 \\
\hline & & & Ст & $118(46]$ & 198 [45] & & \\
\hline & & & $\mathrm{CC}$ & 34 [13] & 53 [12] & & \\
\hline \multirow[t]{3}{*}{6} & rs1800828 & 115374239 & $\mathrm{CC}$ & 148 [58] & 258 (60) & 0.75 & 0.90 \\
\hline & & & CG & 97 (38) & $153[35]$ & & \\
\hline & & & GG & $11[4]$ & 22 (5) & & \\
\hline
\end{tabular}


Munster, B.C. van, Yazdanpanah, M., Tanck, M.W.T., Rooij, S.E.J.A. de, Giessen, E. van de, Sijbrands, E.J.G., Zwinderman, A.H., Korevaar, J.C. Genetic polymorphisms in the DRD2, DRD3, and SLC6A3 gene in elderly patients with delirium. American Journal of Medical Geneticsi-Part 7 B: Neuropsychiatric Genetics: 2010, 153B(1), 38-45

Table 3

\begin{tabular}{|c|c|c|c|c|c|}
\hline Identification & $\begin{array}{c}\text { One-SNP-model OR } \\
{[95 \% \mathrm{Cl}]}\end{array}$ & $P$-value & FDR & $\begin{array}{c}\text { Multi-SNP-model OR } \\
{[95 \% \mathrm{Cl}]}\end{array}$ & $P$-value \\
\hline \multicolumn{6}{|l|}{ DRD2 } \\
\hline rs6276 & 1.0 & 0.006 & 0.064 & 1.0 & 0.002 \\
\hline $\mathrm{AG} / \mathrm{AA}$ & $0.69[0.45-1.05]$ & & & $0.62[0.39-1.0]$ & \\
\hline GG/AA & $0.35(0.18-0.68)$ & & & $0.29(0.14-0.59)$ & \\
\hline rs627? & 1.0 & 0.005 & 0.064 & - & \\
\hline СТ/TT & $0.59[0.37-0.94]$ & & & & \\
\hline $\mathrm{CC} / \mathrm{TT}$ & $0.40(0.23-0.70)$ & & & & \\
\hline rs2734839 & 1.0 & 0.036 & 0.13 & - & \\
\hline $\mathrm{AG} / \mathrm{AA}$ & $0.79[0.51-1.20]$ & & & & \\
\hline GG/AA & $0.45[0.25-0.83)$ & & & & \\
\hline \multicolumn{6}{|l|}{ SLC6A3 } \\
\hline rs1042098 & 1.0 & 0.022 & 0.12 & 1.0 & 0.036 \\
\hline $\mathrm{CT} / \mathrm{TT}$ & $0.56[0.37-0.85]$ & & & $0.55[0.35-0.88]$ & \\
\hline $\mathrm{CC} / \mathrm{TT}$ & $0.85(0.36-2.00)$ & & & $1.00[0.36-2.79]$ & \\
\hline rs40184 & 1.0 & 0.030 & 0.13 & - & \\
\hline $\mathrm{AG} / \mathrm{GG}$ & $0.60[0.38-0.94]$ & & & & \\
\hline AA/GG & $1.03[0.59-1.78)$ & & & & \\
\hline rs1113376? & 1.0 & 0.032 & 0.13 & - & \\
\hline $\mathrm{AG} / \mathrm{GG}$ & $0.61[0.40-0.92]$ & & & & \\
\hline AA/GG & $0.53[0.27-1.04]$ & & & & \\
\hline rs37022 & 1.0 & 0.015 & 0.096 & - & \\
\hline $\mathrm{AT} / \mathrm{TT}$ & $0.92[0.60-1.41]$ & & & & \\
\hline AA/TT & $0.20[0.07-0.59]$ & & & & \\
\hline rs2975292 & 1.0 & 0.047 & 0.15 & - & \\
\hline $\mathrm{CG} / \mathrm{CC}$ & $1.13[0.73-1.73]$ & & & & \\
\hline $\mathrm{GG} / \mathrm{CC}$ & $0.55(0.30-0.98)$ & & & & \\
\hline rs 393795 & 1.0 & 0.004 & 0.064 & 1.0 & 0.004 \\
\hline $\mathrm{AC} / \mathrm{CC}$ & $1.29[0.85-1.96]$ & & & $1.42[0.89-2.28]$ & \\
\hline $\mathrm{AA} / \mathrm{CC}$ & $0.20[0.07-0.59]$ & & & $0.20[0.06-0.63]$ & \\
\hline rs2617605 & 1.0 & 0.011 & 0.088 & - & \\
\hline $\mathrm{AG} / \mathrm{AA}$ & $0.50[0.32-0.79]$ & & & & \\
\hline GG/AA & $0.68[0.39-1.16)$ & & & & \\
\hline
\end{tabular}

